\title{
Viability of Inga vera Willd. subsp. affinis (DC.) T. D. Penn. embryos according to the maturation stage, fungal incidence, chemical treatment and storage ${ }^{1}$
}

\author{
João José Dias Parisi²*, João Domingos Biagi³, Cláudio José Barbedo4, \\ Priscila Fratin Medina ${ }^{2}$
}

\begin{abstract}
The main strategies for conserving Inga vera seeds during storage consist of their partial dehydration and low temperatures. However, such storage conditions can lead to further deterioration of the seed, either from its own metabolism or the development of microorganisms favored by moisture. In this study, the relationship between fungi and the conservation of $I$. vera embryos with different levels of hydration and maturity was studied, together with the efficiency of treating with carboxin + thiram ( $300 \mathrm{~mL} / 100 \mathrm{~kg}$ of embryos) for fungus control. Embryos were collected at two stages (immature and mature) and subjected to two drying levels. A sample of embryos from each stage and drying level was treated with carboxin + thiram. Embryos were then stored at 7 or $25^{\circ} \mathrm{C}$ for up to 65 days. It was found that undried, mature embryos have a higher physiological quality than the immature ones after storage at $7{ }^{\circ} \mathrm{C}$ for 65 days. The carboxin + thiram treatment is phytotoxic for dried embryos. "Field" fungi develop according to the degree of embryo deterioration, differing from the classic pattern defined for orthodox seeds.
\end{abstract}

Index terms: pathogen, seeds treatment, recalcitrant seeds, storage

Viabilidade de embriões de Inga vera Willd. subsp. affinis (DC.) T. D. Penn. em função do estádio de maturação, da incidência de fungos, do tratamento químico e do armazenamento

\begin{abstract}
RESUMO - As principais estratégias para a conservação de sementes de Inga vera durante o armazenamento consistem na desidratação parcial e no uso de baixas temperaturas. Contudo, tais condições ainda podem conduzir à deterioração, tanto pela atividade do seu próprio metabolismo, como pelo desenvolvimento de micro-organismos favorecidos pela umidade. Neste trabalho objetivou-se analisar o grau de interferência dos fungos na conservação de embriões de $I$. vera com diferentes níveis de hidratação e de maturidade, bem como a eficiência do carboxin + thiram $(300 \mathrm{~mL} / 100 \mathrm{~kg}$ de embriões $)$ no controle desses fungos. Para tanto, embriões foram colhidos em duas fases (imaturos e maduros) e submetidos a dois níveis de secagem. De cada fase e nível de secagem, uma amostra foi tratada com carboxin + thiram. Embriões de todos os tratamentos foram armazenados sob $7 \mathrm{e}$ $25^{\circ} \mathrm{C}$ por até 65 dias. Constatou-se que embriões maduros, sem secagem e armazenados a $7{ }^{\circ} \mathrm{C}$ por 65 dias apresentaram maior potencial fisiológico em relação aos imaturos. O tratamento com carboxin + thiram causa fitotoxicidade nos embriões submetidos à secagem. Foi constatada a presença de fungos considerados como de "campo" durante o armazenamento, simultaneamente à deterioração dos embriões, diferindo do padrão clássico definido com base em sementes ortodoxas.
\end{abstract}

Termos para indexação: patógeno, tratamento de sementes, sementes recalcitrantes, armazenamento.

\section{Introduction}

The seeds of different native forest species have characteristics, which give them a greater or lesser longevity

\footnotetext{
${ }^{1}$ Submitted on 03/23/2012. Accepted for publication on 10/09/2012.

${ }^{2}$ Instituto Agronômico de Campinas, Centro de Pesquisa e Desenvolvimento de Fitossanidade Laboratório de Sementes, Caixa Postal 28, 04301-012 - Campinas, SP, Brasil.

${ }^{3}$ Universidade Estadual de Campinas, Caixa Postal 6011, 13083-970 - Campinas, SP, Brasil.
}

during storage. Among these characteristics, the level of tolerance to desiccation, that is, the capacity to support the removal of large quantities of water, appears to be one of the main conditioners of seed longevity. Therefore, there is

\footnotetext{
${ }^{4}$ Instituto de Botânica, Núcleo de Pesquisa em Sementes, Caixa Postal 68041, 04045-972 - São Paulo, SP, Brasil.

*Corresponding author<jparisi@iac.sp.gov.br>
} 
a close and direct relationship between this tolerance and the capacity to maintain viability during prolonged storage.

Among the native forest species, Inga vera, known in Brazil as "ingá", is common in riparian forests in São Paulo state, performing a fundamental role in the recuperation of degraded areas along rivers, streams and springs (Bilia et al., 2003). The seeds of this species are included among the most intolerant to desiccation and have an extremely short, natural longevity (Bonjovani and Barbedo, 2008). For this reason, from the scientific point of view, this species has been considered very interesting study material by researchers for more than 50 years (Bilia et al., 2003). Some authors describe techniques for increasing seed conservation in I. vera during storage, principally using low temperatures (Andréo et al., 2006; Bonjovani and Barbedo, 2008). However, such conditions may still result in seed deterioration, due to the seed's own metabolism as well as from microorganism development favored by humidity.

A high water content favors a high metabolic activity in seeds and also the survival and proliferation of fungi but the composition of the mycota associated with these seeds may differ between species and also in different development stages (Sutherland et al., 2002). These fungi may cause various types of damage in seeds when these germinate and start seedling production, including death at pre-emergence, root rot, plant collapse, dead areas on leaves, stems and fruits, deformations, underdevelopment, tissue discoloration and latent infections. However, there may be direct damage to the seed, such as rotting and losses in germinative power, resulting in a lower production of nursery plants and increases in reforestation costs. The confirmation of damage in seeds intolerant to desiccation is made more difficult by their short longevity and there are doubts as to whether seeds offer conditions for fungal growth or if the mycota itself causes seed debilitation. Berjak (1995), for example, considered that both factors can be happening simultaneously.

The pathogen $\mathrm{x}$ host relationship in seeds intolerant to desiccation is still not fully understood, principally during storage. The metabolic modifications resulting from this relationship, for example, and their physiological implications for the process still need to be clarified. This knowledge is essential for developing technologies which will allow the management and conservation of these seeds for longer periods. Therefore, the objective of this study was to analyze the degree of fungal interference in the conservation of Inga vera embryos, with different levels of hydration and maturity as well as the efficiency of treating with carboxin + thiram at a dosage of $300 \mathrm{~mL}$ per $100 \mathrm{~kg}$ of embryos, with the aim of maintaining viability during storage.

\section{Material and Methods}

Inga vera fruits were harvested in 2009 from branches tagged on 30 trees located in parks near the river Piracicaba, Piracicaba county, São Paulo state. Based on results from Andréo et al. (2006) and Bonjovani and Barbedo (2008), fruits were collected in two maturation stages, identified by the coloration of the peel at harvest and classified according to Munsell (1952) as Greenish Green-yellow (7.5 GY 6/10) and Yellowish (7.8 GY 8/10).

The seeds were manually removed from the fruits and those damaged by insects were discarded. The sarcotestas were then removed and the excised embryos were stored in plastic bags, placed in a BOD-type chamber with the temperature at a constant $7{ }^{\circ} \mathrm{C}$, with no light, until the beginning of the experiments, which occurred less than seven days after harvest.

After being homogenized, the embryos were divided manually using a ruler into two samples for each maturation stage: the initial water content was determined in the first sample and the second sample was partially dehydrated up to the desiccation limit of 49 to $51 \%$, considered suitable by Bilia et al. (1998) for 60 days of storage, using forced air oven at $30{ }^{\circ} \mathrm{C}$. Periodically, seed samples submitted to drying were removed and weighed to verify the reduction in water content. The water content of immature embryos was reduced to $55 \%$ due to their higher sensitivity to drying.

Embryo samples from each combination between the maturation stage and the dehydration level were submitted to a treatment with carboxin + thiram, which has a wide activity spectrum, at a dosage of $300 \mathrm{~mL}$ of commercial product per $100 \mathrm{~kg}$ of embryos. This is the dosage recommended for crop plants since no chemical products are registered for forest species. Distilled water at a ratio of $0.5 \%$ of the weight of the embryo samples was added to both treated and untreated treatments. The application of fungicide and distilled water was done in $5 \mathrm{~L}$ plastic bags, shaken for 5 minutes. The treatments corresponding to the eight samples (with and without drying and treated or not with fungicides, for each maturation stage) were placed in impermeable, transparent, polyethylene bags ( 30 x $40 \mathrm{~cm}$ wide and long, $2 \mathrm{~mm}$ thick, $6.5 \mathrm{~L}$ volume) resistant to gas exchanges up to about $1 / 4$ of the volume. These were rolled up manually and stored at 7 and $25^{\circ} \mathrm{C}$. The embryos were evaluated for water content, germination, dry weight and sanitation before storage and after 35 and 65 days.

The water content was determined by the oven method with forced air at $103{ }^{\circ} \mathrm{C}$ for 17 hours (Brasil, 2009), with four replications of five embryos. The results were expressed as a percentage on a wet basis. 
The germination test was done by the paper roll method, with two sheets for the base and one for covering (Brasil, 2009), in germinators with water in the bottom, continuous light and a temperature of $25^{\circ} \mathrm{C}$ (Bonjovani and Barbedo, 2008). Evaluations were made on four replications, each with 15 embryos, every two days until the $14^{\text {th }}$ day after the beginning of the trial, noting the percentage embryos showing a minimum $1 \mathrm{~cm}$ of primary root.

The dry weight was measured after the end of the germination test, separating the aerial part from the roots for all the seedlings of each treatment, and placing the materials in an oven to dry for 24 hours at $80{ }^{\circ} \mathrm{C}$. The seedling dry weight was calculated by dividing the value of the dry weight obtained by the number of embryos which germinated and expressing the result in mg per seedling (Nakagawa, 1999).

The sanitary test was done by the filter paper method (Parisi and Santos, 2011), where the embryos are incubated in $9 \mathrm{~cm}$-diameter Petri dishes containing three sheets of filter paper, moistened with distilled water. The plates containing 10 embryos, equidistant from each other, were kept for seven days at $20 \pm 2{ }^{\circ} \mathrm{C}$, under a 12 hour photoperiod. Evaluations were made on four replications with 15 embryos each, observing fungal structures on the embryos with a stereoscopic and optical microscopes.

The experimental design was completely randomized with a $4 \times 2 \times 3$ factorial (drying and fungicide treatment $\times$ storage temperature $\mathrm{x}$ storage period) for each maturation stage. The results were submitted to an analysis of variance at the $5 \%$ probability level. Where necessary, the means were compared using the Tukey test at the $5 \%$ probability level. The statistical analyses were done with the SISVAR program (Ferreira, 2003) and, when necessary, the data were transformed to log (x) e $\sqrt{x}+0.5$ to correct normality and heterogeneity (Santana and Ranal, 2004).

\section{Results and Discussion}

The water contents of the Inga vera embryos observed after cleaning, drying and treating in January 2009 were close to the expected values; an average of 61 and $56 \%$, respectively for mature embryos, without and with drying, and 59 and $51 \%$ for immature embryos without and with drying were observed (Table 1).

Table 1. Germination (\%) of immature and mature embryos of Inga vera submitted to different treatments, temperatures and storage periods. Data on the protrusion of the primary root at 14 days.

\begin{tabular}{|c|c|c|c|c|c|c|c|c|}
\hline \multirow{2}{*}{ Water content $(\%)$} & \multirow{2}{*}{ Maturity } & \multirow{2}{*}{ Fungicide* } & \multicolumn{3}{|c|}{$7{ }^{\circ} \mathrm{C}$} & \multicolumn{3}{|c|}{$25^{\circ} \mathrm{C}$} \\
\hline & & & 0 & 35 days & 65 days & 0 & 35 days & 65 days \\
\hline \multirow{2}{*}{61} & \multirow{4}{*}{ immature } & No & $92 \mathrm{aA}$ & $100 \mathrm{aA}$ & $100 \mathrm{aA}$ & $92 \mathrm{aA}$ & $83 \mathrm{aA}$ & $0 \mathrm{bB}$ \\
\hline & & Yes & $95 \mathrm{aA}$ & $100 \mathrm{aA}$ & $100 \mathrm{aA}$ & $95 \mathrm{aA}$ & $58 \mathrm{bB}$ & $18 \mathrm{aC}$ \\
\hline \multirow{2}{*}{56} & & No & $98 \mathrm{aA}$ & $98 \mathrm{aA}$ & $100 \mathrm{aA}$ & $98 \mathrm{aA}$ & $65 \mathrm{abB}$ & $3 \mathrm{bC}$ \\
\hline & & Yes & $98 \mathrm{aA}$ & $93 \mathrm{aA}$ & $70 \mathrm{bB}$ & $98 \mathrm{aA}$ & $10 \mathrm{cB}$ & $2 \mathrm{bC}$ \\
\hline CV (\%) & \multicolumn{8}{|c|}{7.61} \\
\hline \multirow{2}{*}{59} & \multirow{4}{*}{ mature } & No & $100 \mathrm{aA}$ & $100 \mathrm{aA}$ & $100 \mathrm{aA}$ & $100 \mathrm{aA}$ & $80 \mathrm{aA}$ & $5 \mathrm{aB}$ \\
\hline & & Yes & $98 \mathrm{aA}$ & $100 \mathrm{aA}$ & $100 \mathrm{aA}$ & $98 \mathrm{aA}$ & $88 \mathrm{aA}$ & $8 \mathrm{aB}$ \\
\hline \multirow{2}{*}{51} & & No & $100 \mathrm{aA}$ & $100 \mathrm{aA}$ & $100 \mathrm{aA}$ & $100 \mathrm{aA}$ & $82 \mathrm{aA}$ & $5 \mathrm{aB}$ \\
\hline & & Yes & $87 \mathrm{aA}$ & $72 \mathrm{aA}$ & $38 \mathrm{bB}$ & $87 \mathrm{aA}$ & $57 \mathrm{aA}$ & $15 \mathrm{aB}$ \\
\hline
\end{tabular}

Means transformed to $\sqrt{x+0.5}$.

Means followed by the same small letter in the column and capital letter in the row for each temperature do not differ between themselves according to Tukey's test at the $5 \%$ probability level.

*Carboxin + thiram at a dosage of $300 \mathrm{~mL}$ of commercial product per $100 \mathrm{~kg}$ of embryos.

The embryos of all the treatments (Table 1) kept their germinative capacity during the 65 days of storage at $7^{\circ} \mathrm{C}$ and did not require the partial dehydration mentioned by Bilia et al. (1998). This may have been due to possible variations in seed formation in distinct years, to resistance acquired in the maintenance of the germinative capacity of $I$. vera embryos over time or to the greater physiological potential of the embryos used in this study. These results were similar to those observed in Eugenia spp. seeds, regarding the inefficiency of reducing seed water content for prolonging storage (Kohama et al., 2006; Delgado and Barbedo, 2007; Oliveira et al., 2011).

After 35 days at $25^{\circ} \mathrm{C}$, the germination of the mature and immature embryos decreased proportionally with increasing storage period since this condition was not ideal for maintaining embryo viability in this species. Hypothetically, fungus development at higher temperatures is faster and, 
therefore, fungicide treatments should be more beneficial. However, this was not confirmed by the data, that is, the fungi were not the main factor in increased deterioration at $25{ }^{\circ} \mathrm{C}$, but the physiological characteristics of the embryo itself.

There was a decrease in the percentage germination of the mature embryos at 65 days stored at $7{ }^{\circ} \mathrm{C}$ after drying and fungicide treatment, probably due to the phytotoxicity of the product used; a similar result was observed for Eugenia piriformes seeds treated with the same fungicide (Oliveira et al., 2011) and also for Eugenia dysenterica seeds (Gomide et al., 1994). This effect also occurred at 35 days in immature embryos, with and without drying, treated and stored at $25^{\circ} \mathrm{C}$. However, the efficiency of the fungicide treatment on the undried embryos was observed after 65 days storage. There was a greater incidence of fungi under these conditions resulting in a total loss of embryo viability.

The results for the seedling dry weight of each $I$. vera embryo germinated (Table 2), were similar to those of the germination tests (Table 1). Chemical treatment of unstored, immature embryos with their original water content, resulted in higher seedling dry weight compared to the untreated embryos. This advantage did not continue with storage, which may have been due to a loss in the activity of the fungicide used in treating the $I$. vera embryos.

Table 2. Dry weight (mg) of seedlings per immature and mature embryo of Inga vera germinated, submitted to different treatments, temperatures and storage periods.

\begin{tabular}{|c|c|c|c|c|c|c|c|c|c|c|}
\hline \multirow{2}{*}{$\begin{array}{c}\text { Water } \\
\text { content } \\
(\%)\end{array}$} & \multirow[b]{2}{*}{ Maturity } & \multirow[b]{2}{*}{ Fungicide* } & \multicolumn{4}{|c|}{$7^{\circ} \mathrm{C}$} & \multicolumn{4}{|c|}{$25^{\circ} \mathrm{C}$} \\
\hline & & & 0 & 35 days & 65 days & Mean & 0 & 35 days & 65 days & Mean \\
\hline \multirow{2}{*}{61} & \multirow{4}{*}{ immature } & No & $25.9 \mathrm{bA}$ & $27.1 \mathrm{aA}$ & $29.1 \mathrm{aA}$ & & $25.9 \mathrm{bA}$ & $28.3 \mathrm{aA}$ & $0 \mathrm{bB}$ & \\
\hline & & Yes & $36.2 \mathrm{aA}$ & $30.7 \mathrm{aA}$ & $28.3 \mathrm{aA}$ & & $36.2 \mathrm{aA}$ & $25.3 \mathrm{aB}$ & $20.3 \mathrm{aB}$ & \\
\hline \multirow{2}{*}{56} & & No & $34.6 \mathrm{abA}$ & $26.4 \mathrm{aA}$ & $28.7 \mathrm{aA}$ & & $35.1 \mathrm{abA}$ & $22.3 \mathrm{aB}$ & $2.4 \mathrm{bC}$ & \\
\hline & & Yes & $30.6 \mathrm{abA}$ & $22.6 \mathrm{aAB}$ & $21.7 \mathrm{aB}$ & & $30.6 \mathrm{abA}$ & $10.5 \mathrm{bB}$ & $2.0 \mathrm{bC}$ & \\
\hline CV (\%) & \multicolumn{10}{|c|}{10.07} \\
\hline \multirow{2}{*}{59} & \multirow{4}{*}{ mature } & No & 50.8 & 43.5 & 44.7 & $46.3 \mathrm{ab}$ & 50.9 & 36.0 & 6.5 & $31.1 \mathrm{a}$ \\
\hline & & Yes & 57.0 & 51.3 & 44.0 & $50.7 \mathrm{a}$ & 57.0 & 33.8 & 11.2 & $34.0 \mathrm{a}$ \\
\hline \multirow{2}{*}{51} & & No & 50.5 & 44.8 & 44.7 & $46.7 \mathrm{ab}$ & 50.6 & 34.2 & 9.0 & $31.2 \mathrm{a}$ \\
\hline & & Yes & 47.6 & 35.5 & 24.6 & $35.9 \mathrm{~b}$ & 47.6 & 31.0 & 17.3 & $31.9 \mathrm{a}$ \\
\hline Means & & & $51.5 \mathrm{~A}$ & $43.8 \mathrm{AB}$ & $39.5 \mathrm{~B}$ & & $51.5 \mathrm{~A}$ & $33.7 \mathrm{~B}$ & $10.9 \mathrm{C}$ & \\
\hline CV (\%) & & & & & 24.16 & & & & & \\
\hline
\end{tabular}

Means transformed to $\sqrt{x+0.5}$.

Means followed by the same small letter in the column and capital letter in the row for each temperature, do not differ between themselves according to Tukey's test at the $5 \%$ probability level.

*Carboxin + thiram at a dosage of $300 \mathrm{~mL}$ of commercial product per $100 \mathrm{~kg}$ of embryos.

Although the viability of $I$. vera embryos was maintained during the whole storage period at $7{ }^{\circ} \mathrm{C}$, the numerical values of the dry weight of the mature embryos were higher than those of the immature ones for both temperatures, demonstrating the higher physiological potential of the mature embryos, reflected in the conservation of their viability for a longer time period than for the immature embryos at $25{ }^{\circ} \mathrm{C}$. Harvesting before maturity resulted in poor embryo performance since they were still not completely formed and there was a smaller accumulation of dry material and, consequently, a lower physiological potential.

Seven genera of fungi were detected on $I$. vera embryos (Figure 1), including Fusarium oxysporum, Colletotrichum gloeosporioides and Phomopsis diachenii, considered important pathogens of crop species. Most of these fungi were also detected on recalcitrant seeds by Oliveira et al. (2011) and Mittal (2003), also demonstrating their importance on forest species.

Untreated embryos had more genera of fungi and in greater numbers compared to treated embryos. Their incidence varied more as a result of the storage time and temperature rather than the maturation or drying. It should be noted that fungal incidence is similar in both mature and immature embryos with original water contents (Figures $1 \mathrm{~A}$ and $1 \mathrm{E})$. Different results were observed for Brazil wood seeds (Caesalpinia echinata Lam.) by LisbôaPadulla et al. (2010) with an increase in the incidence of Pestalotiopsis maculans, Cladosporium cladosporoides and Fusarium sp. with time and after dispersion for three days. Important fungi, which did not develop in the treated embryos, such as Phoma sp. and C. gloeosporioides, appeared after 35 and 65 days of storage respectively. 

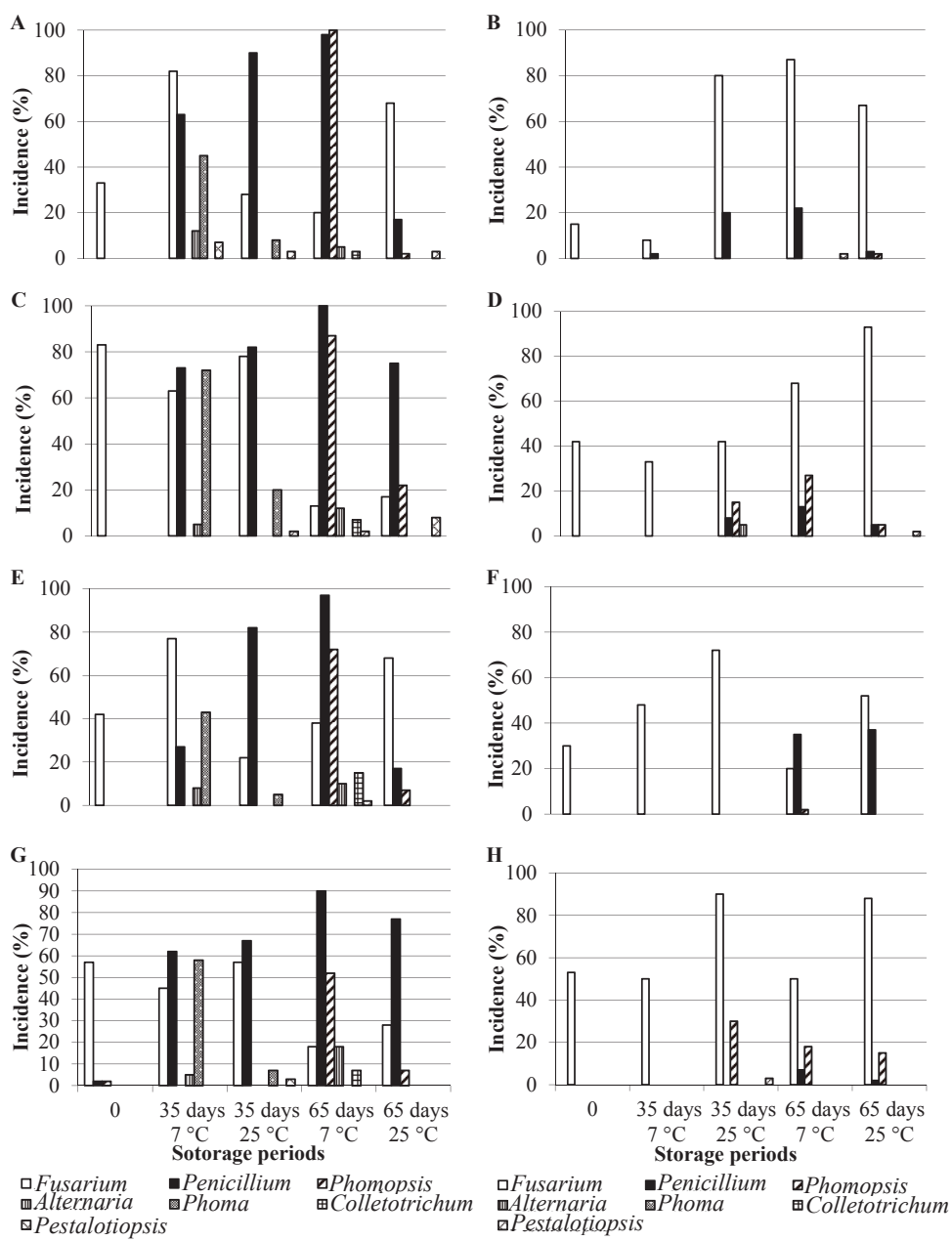

Figure 1. Incidence (\%) of fungi detected on immature (A, B, C and D) and mature (E, F, G and H) embryos of Inga vera with mean water contents of $60(\mathrm{~A}, \mathrm{~B}, \mathrm{E}$ and $\mathrm{F})$ and $50 \%(\mathrm{C}, \mathrm{D}, \mathrm{G}$ and $\mathrm{H})$, untreated with fungicide $(\mathrm{A}, \mathrm{C}, \mathrm{E}$ and $\mathrm{G})$ or treated with Vitavax-Thiram (B, D, F and H), at a dosage of $300 \mathrm{~mL}$ of c.p. $/ 100 \mathrm{~kg}$ of embryos, and stored for 35 and 65 days at 7 and $25^{\circ} \mathrm{C}$.

F. oxysporum was detected on treated embryos independently of the level of water content and maturity but the treatment inhibited development of this fungus over the whole surface of the embryos, facilitating the detection of other fungi. The fungus Pestalotiopsis sp. was identified after 35 days of storage on immature embryos for both water contents; however, development of this species began after 65 days on mature embryos. Drying and the storage temperature of $25{ }^{\circ} \mathrm{C}$ favored the occurrence of Phomopsis diachenii, Pestalotiopsis sp. and Altenaria alternata after 35 days, probably due to embryo deterioration.

Pestalotiopsis sp., Phoma sp., P. diachenii and $C$. gloeosporioides (Figure 1), considered as field pathogens, appeared during the storage period, proving that the classic standard of fungus development for $I$. vera seeds is not similar to that of seeds tolerant to desiccation, principally for agricultural species. These fungi stay on the embryos in a latent form without causing any symptoms until the embryos start to deteriorate. According to Sutton (1992), the mycelium of C. gloeosporioides remains viable for a considerable time on infected embryos, cultural remains and fruits, appearing as soon as conditions become favorable for its development, and also becomes a serious problem after harvest. Latunde-Dada (2001) considered C. gloeosporioides and C. acutatum as quiescent endophytes with a potential to develop symptoms under environmental stress conditions. Fungi of the genus Colletotrichum are important phytopathogens in tropical and subtropical regions of the world. These fungi cause a variety of diseases, such as anthracnose and stem rot in mangos, avocados and papaya (Bailey and Jeger, 1992). This information proves that the results of fungal development on I. vera embryos are similar to those from the fruits since these are detected after ripening and during deterioration. 
A statistical analysis was only done for $F$. oxysporum (Table 3) due to its importance and high incidence in all the treatments. A high level of this fungus can be identified on "inga" embryos stored at 7 and $25^{\circ} \mathrm{C}$, from the start until the 65 days. The variations between treatments must have occurred due to the greater development of other fungi or to contamination by Penicillium sp. The treatment of embryos with carboxin + thiram at $300 \mathrm{~mL}$ of commercial product only gave efficient control of F. oxysporum up to 35 days for immature embryos and was not efficient at 65 days for either mature or immature embryos.

Table 3. Incidence (\%) of Fusarium oxysporum on immature embryos of Inga vera submitted to different treatments, temperatures and storage periods.

\begin{tabular}{|c|c|c|c|c|c|c|c|}
\hline \multirow{2}{*}{ Water content $(\%)$} & \multirow{2}{*}{ Fungicide* } & \multicolumn{3}{|c|}{$7{ }^{\circ} \mathrm{C}$} & \multicolumn{3}{|c|}{$25{ }^{\circ} \mathrm{C}$} \\
\hline & & 0 & 35 days & 65 days & 0 & 35 days & 65 days \\
\hline \multirow{2}{*}{61} & No & $33 \mathrm{bB}$ & $82 \mathrm{aA}$ & $20 \mathrm{bB}$ & $33 \mathrm{bB}$ & $28 \mathrm{bB}$ & $68 \mathrm{aA}$ \\
\hline & Yes & $15 \mathrm{bB}$ & $8 \mathrm{bB}$ & $87 \mathrm{aA}$ & $15 \mathrm{bB}$ & $80 \mathrm{aA}$ & $67 \mathrm{aA}$ \\
\hline \multirow{2}{*}{56} & No & $83 \mathrm{aA}$ & $63 \mathrm{aA}$ & $13 \mathrm{bB}$ & $83 \mathrm{aA}$ & $78 \mathrm{aA}$ & $17 \mathrm{bB}$ \\
\hline & Yes & $42 \mathrm{bB}$ & $33 \mathrm{bB}$ & $68 \mathrm{aA}$ & $42 \mathrm{bB}$ & $42 \mathrm{bB}$ & $93 \mathrm{aA}$ \\
\hline CV (\%) & \multicolumn{7}{|c|}{35.8} \\
\hline \multirow{2}{*}{59} & No & $42 \mathrm{aB}$ & $76 \mathrm{aA}$ & $38 \mathrm{aB}$ & $42 \mathrm{aAB}$ & $22 \mathrm{cB}$ & $68 \mathrm{abA}$ \\
\hline & Yes & $30 \mathrm{aA}$ & $48 \mathrm{aA}$ & $20 \mathrm{aA}$ & $30 \mathrm{aB}$ & $72 \mathrm{abA}$ & $52 \mathrm{bcAB}$ \\
\hline \multirow{2}{*}{51} & No & $57 \mathrm{aA}$ & $45 \mathrm{aAB}$ & $18 \mathrm{aB}$ & $57 \mathrm{aA}$ & $57 \mathrm{bA}$ & $28 \mathrm{cA}$ \\
\hline & Yes & $53 \mathrm{aA}$ & $50 \mathrm{aA}$ & $50 \mathrm{aA}$ & $53 \mathrm{aB}$ & $90 \mathrm{aA}$ & $88 \mathrm{aA}$ \\
\hline
\end{tabular}

Original means.

Means followed by the same small letter in the column and capital letter in the row for each temperature, do not differ between themselves according to Tukey's test at the $5 \%$ probability level.

*Carboxin + thiram at a dosage of $300 \mathrm{~mL}$ of commercial product per $100 \mathrm{~kg}$ of embryos.

Most research on fungal pathogenicity for forest species has been done with seeds tolerant to desiccation, demonstrating the fungal damage caused to seedlings. Few studies have shown fungal damage to intolerant seeds mainly due to their short longevity. There are doubts as to whether embryo deterioration offers conditions for fungi to proliferate or if these weaken embryos. Berjak (1995) stated that both factors are involved simultaneously. According to the author, when the principal inoculum source is removed, the life of recalcitrant seeds is increased and these results demonstrate the role of fungi in the conservation of $I$. vera embryos. The interactions of seeds with storage fungi may considerably accelerate the speed of their deterioration (Marcos-Filho, 2005). According to Oliveira et al. (2011), the presence of microorganisms and the high metabolism of the embryos of $I$. vera affects their deterioration.

Regarding the treatment efficiency of forest seeds with fungicides, most studies have been done with orthodox seeds. For I. vera embryos, the carboxin + thiram mixture, at a dosage of $300 \mathrm{~mL}$ of commercial product, did not control fungi efficiently or improve the germinative capacity during storage, but showed phytotoxicity in mature embryos after drying. Other fungicides and dosages or the reapplication of the treatment at monthly intervals should be tested for control of fungi in I. vera embryos since they have a high metabolism and can degrade the product more easily.

\section{Conclusions}

Mature embryos of Inga vera have a greater storage potential than immature ones.

The carboxin + thiram treatment can cause phytotoxicity to these embryos when dried.

Field fungi are present on the embryos during storage and are associated with their deterioration, differing from the classic standard based on orthodox seeds.

\section{References}

ANDRÉO, Y.; NAKAGAWA, J.; BARBEDO, C.J. Mobilização de água e conservação da viabilidade de embriões de sementes recalcitrantes de ingá (Inga vera Willd. subsp. affinis (DC.) T.D. Pennington). Revista Brasileira de Botânica, v.29, p.309-318, 2006. http://www.scielo.br/pdf/rbb/v29n2/a12v29n2.pdf

BAILEY, A.J.; JEGER, J.M. Colletotrichum: biology, pathology and control .Oxford: British Society for Plant Pathology, 1992. 388p.

BERJAK, P. The role of microorganisms in deterioration during storage of recalcitrant and intermediate seeds. In: OUÉDRAOGO, A.S.; POULSEN, K.; STUBSGAARD, F. Intermediate/recalcitrant tropical forest tree seeds: proceedings of a working on improved methods for handling and storage of intermediate/recalcitrant tropical forest tree seeds. Rome: IPGRI; Denmark: DANIDA, 1995. p.121-126. http://www2.bioversityinternational. org/publications/web_version/67/ch02.htm\#bm13-the $\% 20$ role $\% 20$ of $\% 20$ microorganisms $\% 20$ in $\% 20$ deterioration $\% 20$ during $\% 20$ storage $\% 20 \mathrm{of} \% 20$ 
recalcitrant $\% 20$ and $\% 20$ intermediate $\% 20$ seeds $\% 20$ patricia $\% 20$ berjak

BILIA, D.A.C.; MARCOS-FILHO, J.; NOVEMBRE A.D.C.L. Conservação da qualidade fisiológicsa de sementes de Inga uruguensis Hook. et Arn. Revista Brasileira de Sementes, v.20, p.48-54, 1998. http://www.abrates.org. $\mathrm{br} /$ revista/artigos/1998/v20n1/artigo09.pdf

BILIA, D.A.C.; BARBEDO, C.J.; CICERO, S.M.; MARCOS-FILHO, J. Ingá: uma espécie importante para recomposição vegetal em florestas ripárias, com sementes interessantes para a ciência. Informativo Abrates, v.13, p.26-30, 2003.

BONJOVANI, M.R.; BARBEDO, C.J. Sementes recalcitrantes: intolerantes a baixas temperaturas Embriões recalcitrantes de Inga vera Willd. subsp. affinis (DC.) T.D. Penn. toleram temperatura sub zero. Revista Brasileira de Botânica, v.31, p.345-356, 2008. http://www.scielo.br/pdf/rbb/v31n2/v31n2a17.pdf

BRASIL. Ministério da Agricultura, Pecuária e Abastecimento. Regras para análise de sementes. Ministério da Agricultura, Pecuária e Abastecimento. Secretaria de Defesa Agropecuária. Brasília, DF: MAPA/ACS, 2009. 395p. http://www.agricultura.gov.br/arq_editor/file/laborat\%c3\%b3rio/sementes/ regras $\% 20$ para $\% 20$ analise $\% 20 \mathrm{de} \% 20$ sementes.pdf

DELGADO, L.F.; BARBEDO, C.J. Tolerância à dessecação de sementes de espécies de Eugenia. Pesquisa Agropecuária Brasileira, v.42, p.265-272, 2007. http://www.scielo.br/pdf/pab/v42n2/16.pdf

FERREIRA, D.F. Software Sisvar: Versão 4.6 (Build 6.0). Lavras: DEX/ UFLA, 2003. http://www.dex.ufla.br/ danielff/softwares.htm

GOMIDE, C.; FONSECA, C.E.L.; NASSER, L.C.B.; CHARCHAR, M.J.D.; FARIAS NETO, A.L. Identificação e controle de fungos associados às sementes armazenadas de cagaita (Eugenia dysenterica DC.). Pesquisa Agropecuária Brasileira, v.29, n.6, p.885-890, 1994. http://webnotes.sct. embrapa.br/pdf/pab1994/junho/pab08_jun_94.pdf

KOHAMA, S.; MALUF, A.M.; BILIA, D.A.C.; BARBEDO, C.J. Secagem e armazenamento de sementes de Eugenia brasiliensis Lam. (grumixameira). Revista Brasileira de Sementes, v.28, p.72-78, 2006. http://www.scielo.br/ $\mathrm{pdf} / \mathrm{rbs} / \mathrm{v} 28 \mathrm{n} 1 / \mathrm{a} 10 \mathrm{v} 28 \mathrm{n} 1 . \mathrm{pdf}$

LATUNDE - DADA, A.O. Colletrotrichum: Tales of Forcible entry, steath, transient confinement and breakout. Molecular Plant Pathology, v.2, p.187-198, 2001. http://onlinelibrary.wiley.com/doi/10.1046/j.1464-6722.2001.00069.x/pdf
LISBÔA-PADULLA, T.; MORAES, M.H.D.; BARBEDO, C.J.; BORGES, I.F.; MENTEN, J.O.M.; PASCHOLATI, S.F. Detecção de fungos em sementes de pau-brasil (Caesalpinia echinata) coletadas durante sua formação e dispersão. Revista Brasileira de Sementes, v.32, p.154-159, 2010. http://www. scielo.br/scielo.php?pid=s0101-31222010000200019escript=sci_arttext

MARCOS-FILHO, J. Fisiologia de sementes de plantas cultivadas. Piracicaba: FEALQ, 2005. 485p.

MITTAL, R.K. Mycoflora of recalcitrant tree seeds and its effects on germination and storability. The Indian Mycological Society. Journal Mycopathologycal Research, v.41, n.2, p.127-134, 2003. University of Calcuta, Kolkata, India. http://direct.bl.uk/bld/placeorder.do?uin=15607751 3 eetoc $=$ rnefrom $=$ searchengine

MUNSELL COLLOR COMPANY. Munsell color charts for plant tissues. Munsell Collor Company, Baltimore. 1952.

NAKAGAWA, J. Testes de vigor baseados no desempenho de plântulas. In: KRZYZANOWSKI, F.C.; VIEIRA, R.D.; FRANÇA-NETO, J.B. (Ed.). Vigor de sementes: conceitos e testes. Londrina: ABRATES. 1999. 218p.

OLIVEIRA, C.F.; OLIVEIRA,D.C.; PARISI,J.J.D.;BARBEDO, C.J.Deterioração de sementes de espéciesbrasileiras de Eugenia em função da incidência e do controle de fungos. Revista Brasileira de Sementes, v.33, n.3, p.520-532, 2011. http://www. scielo.br/scielo.php?pid=S0101-31222011000300015escript=sci_arttext

PARISI, J.J.D.; SANTOS, A.F. Métodos convencionais de detecção de fungos em sementes. In: SANTOS, A.F.; PARISI, J.J.D.; MENTEN, J.O. Patologia de sementes florestais. Colombo: Embrapa Florestas, 2011. cap.4. 236p.

SANTANA, D.G.; RANAL, M.A. Análise da germinação: um enfoque estatístico. Brasília: Ed. Universidade de Brasília, 2004. 248p.

SUTHERLAND, J.R.; DIKMANN, M.; BERJAK, P. (Ed.). Forests tree seed health for germplasm conservation. Rome: IPGRI, 2002. 85p. (Technical Bulletin, n.6). http://www.bioversityinternational.org/fileadmin/ bioversity/publications/pdfs/865_forest_tree_seed_health_for_germplasm_ conservation.pdf? cache $=1330767484$

SUTTON, B.C. The Genus Glomerella and it's anamorph Colletotrichum. In: BAILEY, J.A, JEGER, M.J. (Ed.). Colletotrichum: biology, pathology and control. Wallingford, U.K.: CAB International. 1992, p.1-26. http://www.cabdirect.org/ abstracts/19932328417.html;jsessionid=2e9b969e6052121a4d24870f3a4a2c22. 